University of Nebraska - Lincoln

DigitalCommons@University of Nebraska - Lincoln

USDA National Wildlife Research Center - Staff Publications
U.S. Department of Agriculture: Animal and Plant Health Inspection Service

February 2003

\title{
IMPACT OF BLACKBIRD DAMAGE TO SUNFLOWER: BIOENERGETIC AND ECONOMIC MODELS
}

\author{
Brian D. Peer \\ Department of Biological Sciences, North Dakota State University, Fargo
}

H. Jeffrey Homan

USDA National Wildlife Research Center, Great Plains Field Station

George M. Linz

USDA/APHIS/WS National Wildlife Research Center, george_m_linz@yahoo.com

William J. Bleier

Department of Biological Sciences, North Dakota State University, Fargo

Follow this and additional works at: https://digitalcommons.unl.edu/icwdm_usdanwrc

Part of the Environmental Sciences Commons

Peer, Brian D.; Jeffrey Homan, H.; Linz, George M.; and Bleier, William J., "IMPACT OF BLACKBIRD DAMAGE TO SUNFLOWER: BIOENERGETIC AND ECONOMIC MODELS" (2003). USDA National Wildlife Research Center - Staff Publications. 231.

https://digitalcommons.unl.edu/icwdm_usdanwrc/231

This Article is brought to you for free and open access by the U.S. Department of Agriculture: Animal and Plant Health Inspection Service at DigitalCommons@University of Nebraska - Lincoln. It has been accepted for inclusion in USDA National Wildlife Research Center - Staff Publications by an authorized administrator of DigitalCommons@University of Nebraska - Lincoln. 


\title{
Using Color-infrared Photography and GIS to Quantify Cattail Coverage in Wetlands
}

\author{
H. Jeffrey Homan, Linda B. Penry, and George M. Linz \\ USDA, Wildlife Services, National Wildlife Research Center, Bismarck, ND
}

\section{Introduction}

Analyzing changes in habitat features at very large scales requires digital images with both high spatial and spectral resolutions. As part of an experiment to reduce blackbird (Icterinae) damage to sunflower, we used large-scale color-infrared photography to monitor regrowth of herbicide-treated cattail (Typha spp.) in wetlands used by roosting blackbirds. In this presentation we describe the methods used to collect, convert, interpret, and analyze high resolution images.

\section{Methods}

Data Collection: We used a SLR 35-mm camera loaded with Kodak Ektachrome ${ }^{\circledR}$ Professional Infrared EIR film. The photographs were shot through a 24-mm lens. A Wratten \#12 filter and haze filter were attached to the lens to counteract blue light effects and improve clarity. Film speed was set manually at EI 100, the recommended speed for the AR- 5 developing process used for infrared accuracy. Shutter speed and aperture settings were $1 / 500 \mathrm{sec}$ and F-5.6, respectively.

We aerially photographed the wetlands at $460-610 \mathrm{~m}$ above ground level. All photographs were taken vertically through a $38-\mathrm{cm}$ diameter port in the floor of the plane's fuselage. To reduce distortion and shadowing of the ground features, photographs were taken nearly perpendicular to the wetlands on cloudless days from 1100 to $1400 \mathrm{~h} \mathrm{CT}$.

Data Conversion: The developed images were scanned at 2100 pixels per inch (ppi) with a Polaroid ${ }^{\circledR}$ Sprint Scan 35 Plus. The scans were converted to Tagged Image Format files. File size was $\sim 16 \mathrm{MB}$.

Data Interpretation: We used ArcView $^{\circledR}$ 3.2a software with the Image Analysis extension to categorize pixels into four

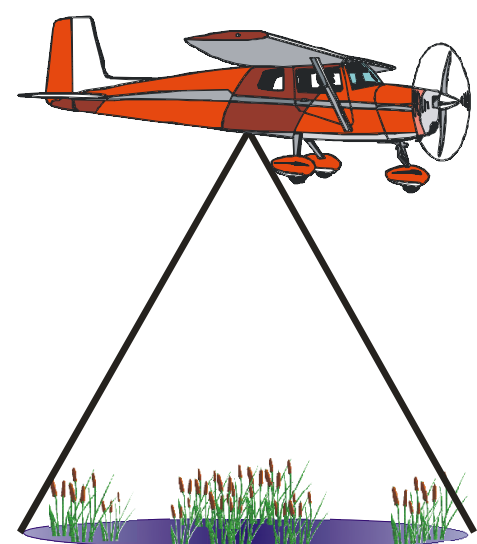
habitat features through a supervised classification. Ground truthing was used to determine the different habitats observed in the scanned images. Living cattail was red, dead cattail was white or pale gray, open water was black, and floating vegetation was fluorescent blue. 
Data Analyses: Annual changes in proportions of living cattail, dead cattail, open water, and floating vegetation were tracked from 1999-2002. A pixel-based coordinate system was used to coregister raster images of wetlands across years. Changes in the proportions of categorized features were tracked through time by summarizing pixel counts between subplots in the wetlands.

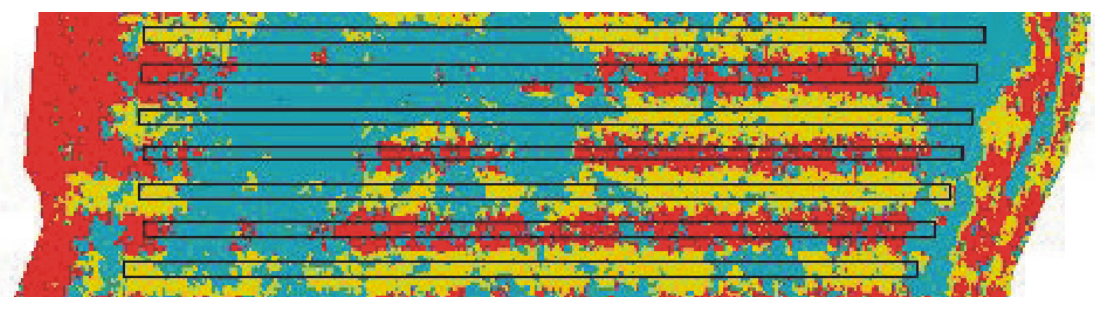

Magnified view of wetland subplots.

\section{Results}

As seen in the images below, the herbicide treatments were applied in a north-south direction alternating with untreated lanes. Over time, the treated cattail decayed, became submerged, and was replaced by open water; whereas, the untreated lanes maintained their structure except for 2001 when high water partially submerged the lanes.

1999
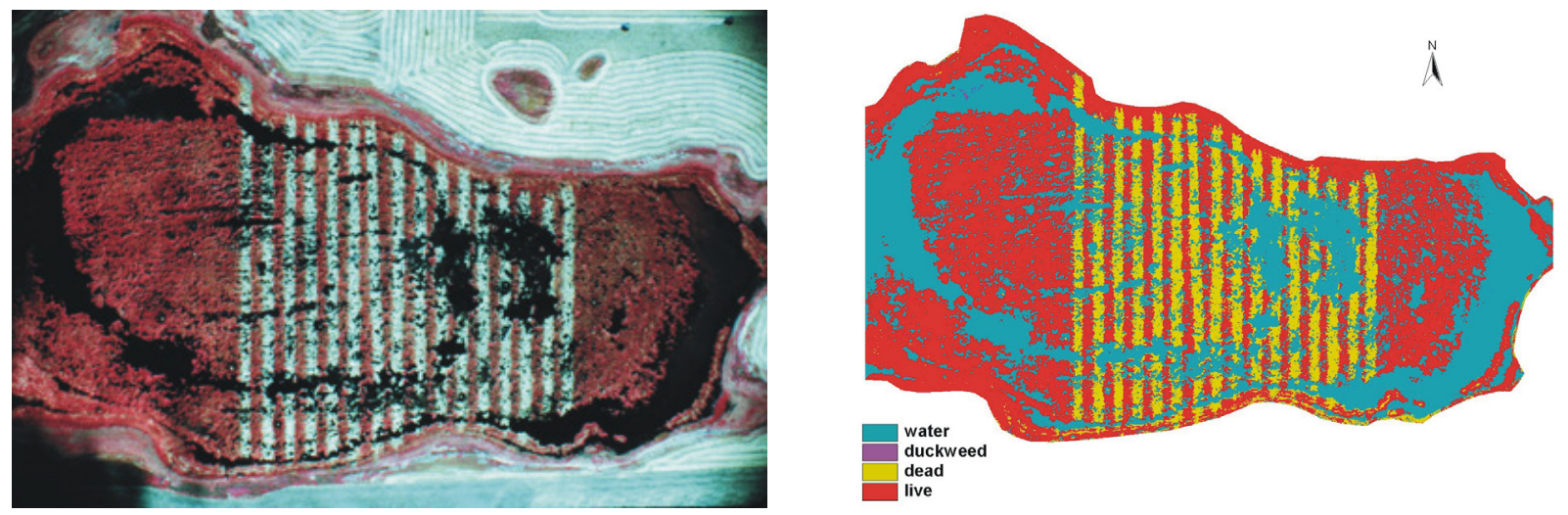

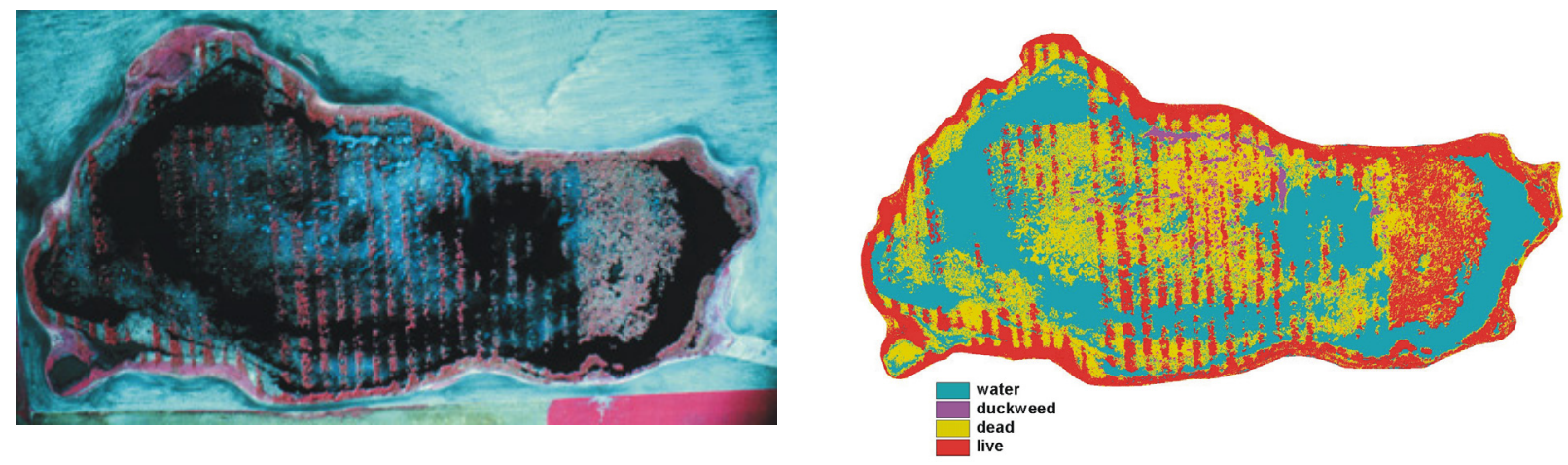

\section{1}
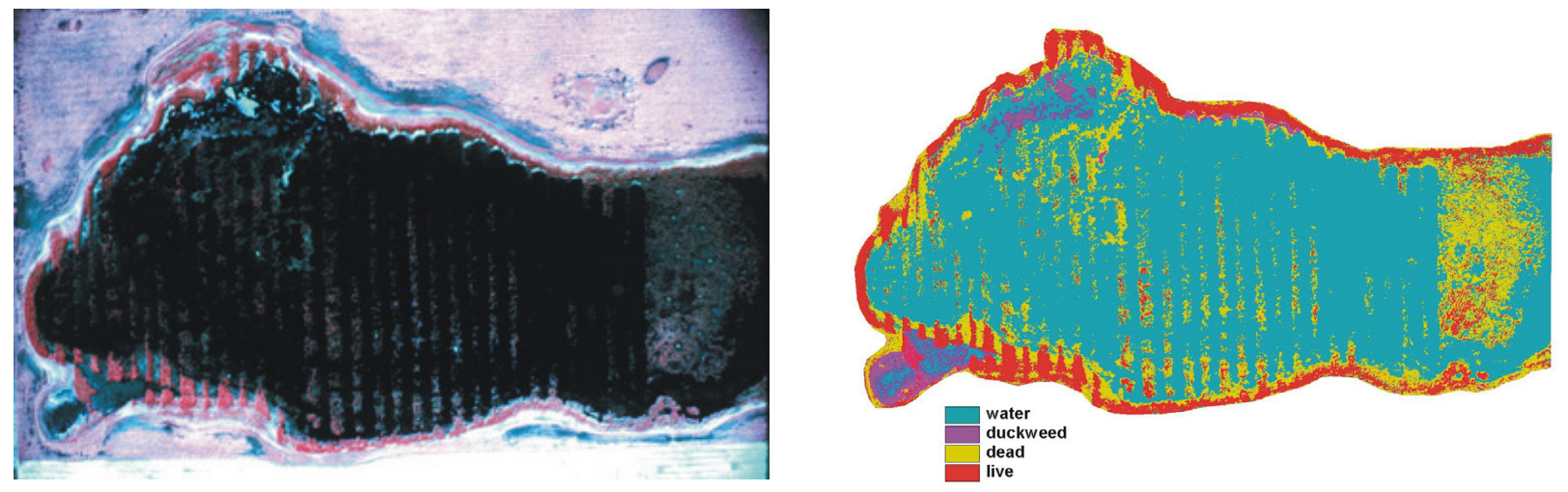

2002
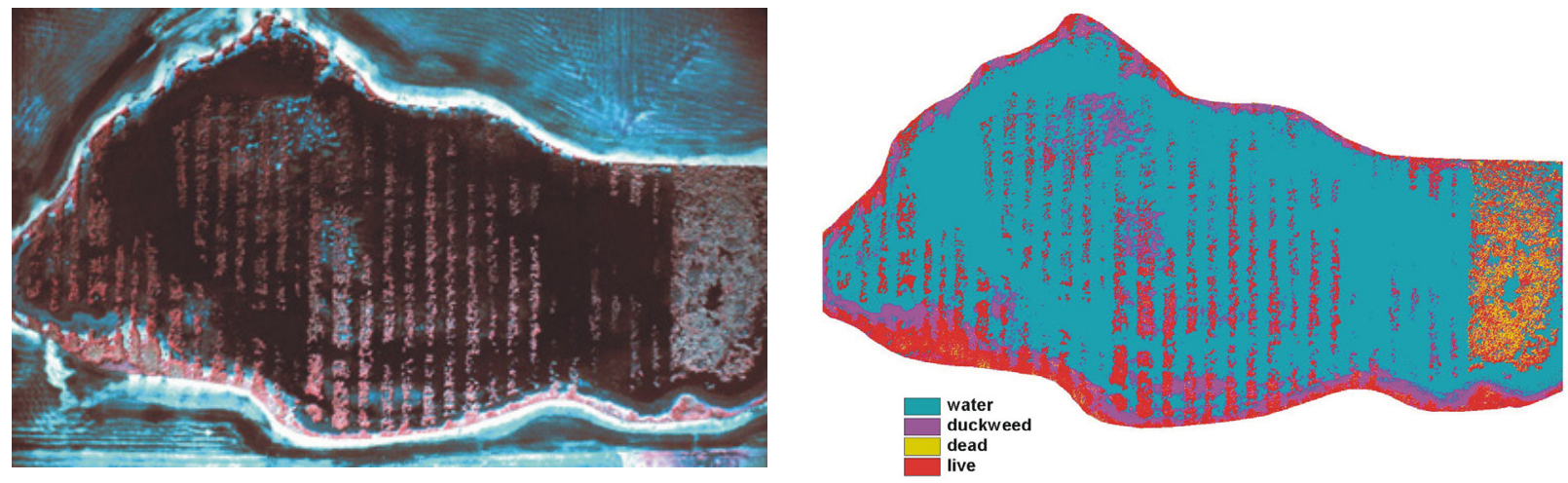
In the tables below are results from one of five wetlands used in the experiment. In this example the herbicide maintained its efficacy across all four years; however, the untreated lanes began to lose some integrity due in part to loss of cattail in the treated lanes.

Changes in percent composition of four habitat features in treated lanes from 1999-2002.

\begin{tabular}{|c|c|c|c|c|}
\hline \multirow{2}{*}{ Year } & \multicolumn{4}{|c|}{ Treated Lanes } \\
\cline { 2 - 5 } & $\begin{array}{c}\text { Live } \\
\text { cattail }\end{array}$ & $\begin{array}{c}\text { Dead } \\
\text { cattail }\end{array}$ & $\begin{array}{c}\text { Open } \\
\text { water }\end{array}$ & $\begin{array}{c}\text { Floating } \\
\text { vegetation }\end{array}$ \\
\hline 1999 & 1 & 59 & 40 & 0 \\
\hline 2000 & 0 & 42 & 54 & 4 \\
\hline 2001 & 0 & 6 & 93 & 1 \\
\hline 2002 & 2 & 0 & 91 & 7 \\
\hline
\end{tabular}

Changes in percent composition of four habitat features in untreated lanes from 1999-2002.

\begin{tabular}{|c|c|c|c|c|}
\hline \multirow{2}{*}{ Year } & \multicolumn{4}{|c|}{ Untreated Lanes } \\
\cline { 2 - 5 } & $\begin{array}{c}\text { Live } \\
\text { cattail }\end{array}$ & $\begin{array}{c}\text { Dead } \\
\text { cattail }\end{array}$ & $\begin{array}{c}\text { Open } \\
\text { water }\end{array}$ & $\begin{array}{c}\text { Floating } \\
\text { vegetation }\end{array}$ \\
\hline 1999 & 57 & 2 & 41 & 0 \\
\hline 2000 & 26 & 30 & 43 & 1 \\
\hline 2001 & 5 & 18 & 77 & 1 \\
\hline 2002 & 18 & 1 & 73 & 8 \\
\hline
\end{tabular}




\section{Discussion}

Although expensive and difficult to use, color-infrared film provides far better information for defining classes of vegetation than color slide film. High spectral sensitivity is needed at large scales because minor inaccuracies in interpretation have profound impacts on the analysis. In this experiment a ground cell resolution of $\sim 1 \mathrm{~m}$ was obtained, which is considered a large scale in GIS analysis.

We have empirical evidence that the images could have been scanned at far less than 2100 ppi. This would have saved on file size without any change in coverages of the habitat features. The resolution of the slide film was in the 4000-5000 ppi range. We consider 2100 ppi an acceptable compromise between file size and ground cell resolution.

By its nature, large-scale photography sacrifices areal coverage for spatial detail. This method can only be applied when working on experiments with relatively small sample sizes. In an average day of flying, we collected 20 images over a 4-hour shooting window; thus, large-scale photography is labor intensive and costly compared to the 15-30 m satellite images (e.g., Landsat) currently used in most GIS analyses. However, several of our techniques to reduce blackbird damage are evaluated at a scale of $<100 \mathrm{~km}^{2}$. At this scale, the methods described above are economically feasible while providing highly detailed data. 